\title{
EFEKTIVITAS CUSTOMER SERVICE (CS) DALAM MENINGKATKAN LOYALITAS NASABAH PENABUNG PADA BANK MUAMALAT CABANG PALANGKA RAYA
}

\author{
*Yenni Octavia ${ }^{1)}$, Rinto Alexandro ${ }^{2)}$ \\ 1)Program Studi Pendidikan Ekonomi Universitas Palangka Raya, Indonesia \\ 2) Program Studi Pendidikan Ekonomi Universitas Palangka Raya, Indonesia \\ *Email Korespondensi : rinto.alexandro@fkip.upr.ac.id
}

\begin{abstract}
Abstrak
Penelitian ini dilatarbelakangi karena pesatnya pertumbuhan perbankan yang saling berkompetisi untuk mencari nasabah ataupun membuat nasabah loyal dengan bank. Ketertarikan masyarakat dan tingkat loyalitas mereka dalam dunia perbankan dilatarbelakangi oleh kualitas pelayanan dan kunci dari pelayanan bank adalah customer service. Dalam penelitian ini peneliti ingin mengetahui sejauh mana efektivitas customer service dalam meningkatkan loyalitas nasabah penabung dan pengguna jasa pada Bank Muamalat Indonesia Cabang Palangka Raya. Proses pengumpulan data dalam penelitian ini melalui metode deskriptif kualitatif. Metode yang penulis gunakan dalam menganalisis data pada penelitian ini adalah induktif dimana data yang berhasil peneliti kumpulkan dari lokasi penelitian, selanjutnya dianalisa dan kemudian disajikan secara tertulis dalam laporan tersebut. Hasil penelitian yang dilakukan di Bank Muamalat Indonesia Kantor Cabang Palangka Raya ini mengenai efektivitas customer service dalam meningkatkan loyalitas nasabah penabung sangatlah penting, hal ini ditunjukkan dengan hasil wawancara yang telah peneliti lakukan yaitu mayoritas sebagian besar kepuasan mereka dan membuat mereka loyal terhadap Bank Maumalat Indonesia Kantor Cabang Palangka Raya. Dengan begitu kualitas pelayanan yang sudah baik dari customer service ini ditingkatkan lagi menjadi taraf yang lebih baik lagi agar nasabah tetap loyal.
\end{abstract}

Kata Kunci: Efektifitas, Loyalitas Nasabah, Customer Service

\begin{abstract}
This research is motivated by the rapid growth of banks that compete with each other to find customers or make customers loyal to the bank. Public interest and their level of loyalty in the banking world is motivated by the quality of service and the key to bank service is customer service. In this study, the researcher wanted to know the extent of the effectiveness of customer service in increasing the loyalty of customers of savers and service users at Bank Muamalat Indonesia, Palangka Raya branch. The process of collecting data in this research is through a qualitative descriptive method. The method that the authors use in analyzing the data in this study is inductive where the data that the researchers managed to collect from the research location
\end{abstract}


were then analyzed and then presented in writing in the report. The results of research conducted at Bank Muamalat Indonesia Palangka Raya Branch Office regarding the effectiveness of customer service in increasing customer loyalty of savers are very important, this is indicated by the results of interviews that researchers have conducted, namely the majority of their satisfaction and making them loyal to Bank Maumalat Indonesia Office Palangka Raya Branch. That way, the good service quality of this customer service is further enhanced to a better level so that customers remain loyal.

Key Words: Effectiveness, Customer Loyalty, Customer Service

\section{PENDAHULUAN}

Seiring dengan kehidupan dunia yang semakin berkembang, transaksi serta kegiatan ekonomi masyarakat tidak dapat dipisahkan dengan keuangan. Maka dari itu banyak masyarakat lebih selektif dalam memilih lembaga-lembaga keuangan yang menurut mereka memberi manfaat antara kedua belah pihak. Pilihan akan lembaga keuangan tersebut pastinya menurut mereka adalah yang terbaik, peran karyawan ataupun seorang pelayan dalam dunia perbankan hendaknya memberikan dampak positif dalam perkembangan dunia perbankan saat ini dan untuk selanjutnya menjadi penopang kemajuan perbankan. Dengan pelayanan yang diberikan pastinya akan lebih banyak masyarakat yang tertarik menggunakan jasa perbankan tersebut.

Saat ini dapat diketahui bahwa perkembangan ilmu pengetahuan dan teknologi berdampak pada persaingan dunia usaha yang semakin meningkat, baik perusahaan yang bergerak di bidang industri, perdagangan maupun jasa, terlebih-lebih pada perusahaan perbankan. Kesuksesan dalam persaingan akan dapat dipenuhi apabila perusahaan bisa menciptakan dan mempertahankan nasabah. Untuk mencapai tujuan tersebut maka perusahaan perbankan memerlukan berbagai usaha agar tujuan yang telah direncanakan dapat tercapai. Salah satu usaha untuk memanjakan nasabahnya adalah melalui pelayanan yang diberikan. Kualitas pelayanan merupakan inti kelangsungan hidup sebuah lembaga penyedia pelayanan, Disamping itu, keberadaan Bank Syariah tidak terlepas pula dari kondisi kehidupan sosial ekonomi masyarakat dan juga memperhatikan aspirasi dan mindset masyarakat (Mujiarto et al., 2019).

Nasabah dibuat senyaman mungkin dengan keramah tamahan dan sopan santun dari para karyawan perusahaan. Nasabah juga dibuat merasa nyaman dalam ruangan yang 
tidak membosankan dengan fasilitas ruangan yang menyenangkan. Sebagai lembaga keuangan, bank memiliki tugas memberikan jasa keuangan melalui penitipan uang (simpanan), peminjaman uang (kredit), serta jasa-jasa keuangan lainnya. Setiap pelaksanaan komponen pengelolaan keuangan harus didasari adanya akuntabilitas atau pertanggungjawaban (Hanum, 2018). Begitupula keuangan di Bank Syariah. Oleh karena itu, bank harus dapat menjaga kepercayaan dari nasabahnya. Kepercayaan sangat penting, karena tanpa kepercayaan mustahil bank dapat hidup dan berkembang (Kasmir,2005:201).

Untuk menjaga dan meningkatkan kepercayaan nasabahnya tersebut maka bank perlu menjaga citra positif dimata masyarakatnya. Citra ini dapat dibangun melalui kualitas produk, kualitas pelayanan, dan kualitas keamanan. Tanpa citra yang positif maka kepercayaan yang sedang dan akan dibangun tidak akan efektif. Sebuah bank syariah selayaknya memiliki lingkungan kerja yang sejalan dengan syariah. Dalam hal etika, misalnya amanah dan siddiq, harus melandasi setiap karyawan sehingga tercermin integritas eksekutif muslim yang baik.

Disamping itu, karyawan bank syariah harus skillful dan profesional (fatanah), dan mampu melakukan tugas secara team-work dimana informasi merata diseluruh fungsional organisasi (Tabliq). Selain itu cara berpakaian dan tingkah laku dari para karyawan merupakan cerminan bahwa mereka bekerja dalam sebuah lembaga keuangan yang membawa nama besar Islam, sehingga tidak ada aurat yang terbuka dan tingkah laku yang kasar. Demikian juga dalam menghadapi nasabah, akhlak harus senantiasa terjaga. Nabi SAW mengatakan bahwa senyum adalah sedekah (Antonio, 2001:34).

Perbankan syariah atau perbankan Islam adalah suatu sistem perbankan yang dikembangkan berdasarkan syariah (hukum) Islam. Usaha pembentukan sistem ini didasari oleh larangan dalam agama Islam untuk memungut maupun meminjam dengan bunga atau yang disebut dengan riba serta larangan investasi untuk usaha-usaha yang dikategorikan haram (misalnya: usaha yang berkaitan dengan produksi makanan/minuman haram, usaha media yang tidak Islami dll), dimana hal ini tidak dapat dijamin oleh sistem perbankan konvensional (Tan, 2009:61).

Bank juga memiliki peranan penting dalam peningkatan kesejahteraan masyarakat. Peningkatan kesejahteraan masyarakat merupakan kerja keras dalam mencari ide dan 
gagasan dalam memberdayakan potensi yang dimiliki daerah. Hal ini sebagai bentuk pengembangan ekonomi kreatif masyarakat (Suwarno \& Bramantyo, 2019)

Kemunculan bank-bank syariah ini merupakan kabar gembira bagi masyarakat Indonesia terutama bagi umat Islam. Karena bank-bank syariah ini pada pelaksanaanya menggunakan sistem bagi hasil, bukan bunga seperti pada bank konvensional. Apalagi saat ini perdebatan mengenai hukum bunga bank dalam Islam masih terus berlanjut. Ada sebagian kalangan yang menghalalkan bunga bank, dan ada sebagian lain yang mengharamkan dan menyamakannya dengan riba. Sedangkan kita tahu bahwa Islam sangat melarang umatnya memakan harta yang diperoleh dari riba. Sehingga kemunculan bank-bank Islam ini diharapkan dapat menjadi solusi alternatif untuk keluar dari permasalahan diatas, selain itu dapat menarik masyarakat terutama yang beragama Islam untuk menabung, dan melakukan pembiayaan atau menggunakan jasa di perbankan syariah.

Salah satu aktivitas bank terutama bank syariah adalah memberikan pelayanan jasa perbankan bagi konsumennya (nasabah) yang berpedoman pada syariah Islam yaitu AlQuran dan As-Sunah. Mulai dari sistem, operasional, dan prosedur kerja pada bank syariah dan produk jasanya harus sesuai dengan konsep syariah. Seluruh aktivitas bank selalu memperhatikan service (pelayanan). Dalam hal pelayanan posisi sumber daya manusia (SDM) paling menentukan dibandingkan dengan mesin atau perangkat apapun yang ada dalam perusahaan. Jadi untuk meningkatkan citra perbankan maka bank perlu menyiapkan karyawan atau sumber daya manusia yang mampu menangani keinginan dan kebutuhan nasabahnya. Karyawan yang diharapkan dapat melayani keinginan dan kebutuhan nasabah ini kita sebut Customer Service (CS) (Kasmir,2005:201).

Pelayanan nasabah atau customer service (CS) disini maksudnya adalah pelayanan nasabah yang mempunyai tugas memberikan informasi mengenai produk atau jasa yang akan dipasarkan (Taylor et al., 2004). Hal demikian dimungkinkan karena kesesuaian, kejelasan informasi atau spesifikasi produk atau jasa secara terperinci merupakan hal yang dapat menunjang kelancaran hubungan antara pihak bank dan nasabah. Oleh karena itu pelayanan kepada nasabah ini merupakan persoalan pokok dalam persaingan antar bank, 
juga merupakan bagian yang tidak terpisahkan dari perusahaan, karena pelayanan nasabah merupakan salah satu kegiatan perusahaan untuk meningkatkan kepuasan nasabah.

Peranan customer service juga merupakan salah satu sumber daya manusia yang diperlukan oleh suatu perusahaan. Dalam melakukan pelayanan peranan dari customer service ini berhubungan langsung dengan pilihan konsumen, maka diperlukan customer service yang handal. Pengertian customer service secara umum adalah setiap kegiatan yang diperuntukkan atau ditujukan untuk memberikan kepuasan nasabah, melalui pelayanan yang dapat memenuhi keinginan dan kebutuhan nasabah.

Customer service memegang peranan yang sangat penting sebagai ujung tombak bank dalam menghadapi nasabah. Dalam dunia perbankan tugas utama seorang CS yaitu memberikan pelayanan dan membina hubungan dengan masyarakat. CS juga harus dapat menjaga nasabah lama agar tetap menjadi nasabah bank (Kasmir,2005:275).

Customer service tidak hanya menjaga nasabah lama tetapi juga harus meningkatkan loyalitas nasabah pada bank yang bersangkutan. Ada beberapa faktor yang mempengaruhi loyalitas nasabah, antara lain adalah kepuasan, kepercayaan, dan komitmen dari nasabah itu sendiri. Kepuasaan hanya salah satu diantara beberapa penyebab terbentuknya loyalitas nasabah. Jadi mempertahankan nasabah sama dengan mempertahankan kelangsungan hidup perusahaan terutama perusahaan di bidang perbankan, hal ini disebabkan karena dengan mempertahankan nasabah, berarti dapat meningkatkan penerimaan atau pendapatan perusahaan dalam penjualan produk.

Sehubungan dengan pentingnya customer service tersebut, maka hal ini perlu diperhatikan oleh perusahaan yakni perusahaan yang bergerak dibidang jasa perbankan. Dalam upaya untuk lebih meningkatkan jumlah nasabah, serta menciptakan loyalitas nasabah agar tidak beralih ke bank lainnya, maka upaya yang dilakukan oleh perusahaan adalah dengan menerapkan customer service yang mampu memberikan pelayanan yang maksimal kepada setiap nasabahnya. Oleh karena itu untuk mengantisipasi persaingan yang semakin ketat dengan perbankan lainnya maka perlu diciptakan hubungan yang baik dengan para nasabah, baik nasabah lama maupun calon nasabah, untuk menciptakan loyalitas nasabah khususnya nasabah penabung. 
Bank Muamalat Indonesia Kantor Cabang Palangka Raya merupakan salah satu lembaga keuangan yang dalam menjalankan kegiatan usahanya selalu mengutamakan kepuasan nasabah diantaranya melayani masyarakat yang ingin menabung dan juga memberikan fasilitas pinjaman kepada masyarakat yang ingin membutuhkan. Strategi pelayanan yang diterapkan meliputi tiga komponen, yaitu mencakup people (karyawan bank), process (proses), dan physical evidence (bukti fisik).

Berdasarkan uraian di atas maka penulis tertarik untuk melakukan penelitian mengenai "Efektivitas customer service dalam meningkatkan loyalitas nasabah penabung pada Bank Muamalat Indonesia Kantor Cabang Palangka Raya”. Penelitian saya ini memilih Bank Muamalat Indonesia sebagai obyek penelitian karena dianggap representative sebagai salah satu bank syariah yang sedang berkembang saat ini dan Bank Muamalat Indonesia ini merupakan Bank Syariah pertama yang berdiri di Indonesia.

\section{TINJAUAN PUSTAKA}

Di Indonesia pelopor perbankan syariah adalah Bank Muamalat Indonesia. Berdiri tahun 1991, bank ini diprakarsai oleh Majelis Ulama Indonesia (MUI) dan pemerintah serta dukungan dari Ikatan Cendekiawan Muslim Indonesia (ICMI) dan beberapa pengusaha muslim. Setelah Bank Muamalat disusul Bank Syariah Mandiri pada tahun 1999 dan beberapa Unit Usaha Syariah. Saat ini keberadaan bank syariah di Indonesia telah di atur dalam Undang-Undang yaitu UU No. 10 tahun 1998 tentang perubahan UU No. 7 tahun 1992 tentang perbankan yang memberikan landasan hukum yang lebih kuat bagi keberadaan sistem perbankan syariah.Pengertian bank menurut Undang-Undang No. 10 Tahun 1998 bank adalah badan usaha yang menghimpun dana dari masyarakat dalam bentuk simpanan dan menyalurkannya ke masyarakat dalam bentuk kredit atau bentukbentuk lainnya dalam rangka meningkatkan taraf hidup rakyat banyak.

Loyalitas berasal dari kata dasar "Loyal" yang berarti setia, atau loyalitas dapat diartikan sebagai suatu kesetiaan. Loyalitas Pelanggan adalah komitmen pelanggan bertahan secara mendalam untuk berlangganan kembali atau melakukan pembelian ulang produk/jasa terpilih secara konsisten dimasa yang akan datang, meskipun pengaruh situasi dan usaha-usaha pemasaran mempunyai potensi untuk menyebabkan perubahan perilaku 
(Hurriyati, 2014:129). Loyalitas pelanggan adalah kunci sukses suatu usaha dalam menjalin hubungan jangka panjang antara perusahaan dengan pelanggannya. Demikian pula dengan Bank Muamalat Indonesia yang berupaya untuk menjalin hubungan kerjasama tersebut sebaik-baiknya dengan para nasabahnya melalui peran customer service.

\section{METODE PENELITIAN}

Jenis penelitian ini adalah penelitian kualitatif. Di dalam penelitian ini penulis menggunakan jenis penelitian Kualitatif. Penelitian ini merupakan penelitian deskriptifkualitatif. Fokusnya adalah penggambaran secara menyeluruh tentang bentuk, fungsi, dan makna ungkapan larangan. Penelitian dilakukan di kantor Bank Muamalat Indonesia Cabang Palangka Raya yang terletak di jalan Diponegoro Kota Palangka Raya. Pemilihan lokasi ini dengan pertimbangan bahwa jarak lokasi penelitian dengan tempat tinggal peneliti dan sarana transportasi yang mudah untuk dijangkau.

Subjek penelitian adalah orang-orang yang memberikan informasi yang bersangkutan dengan judul penelitian. Dalam penelitian ini, peneliti menggunakan teknik purposive sampling yaitu teknik pengambilan sampel yang didasarkan atas tujuan tertentu (orang dipilih betul-betul memiliki kriteria sebagai sampel). Sampel didalam penelitian ini nantinya diambil berdasarkan pertimbangan tertentu yaitu pemilihan sampel berdasarkan permasalahan yang ada didalam penelitian ini yaitu mengenai efektivitas customer service dalam meningkatkan loyalitas nasabah penabung pada Bank Muamalat Indonesia Cabang Palangka Raya. Terkait didalam penelitian ini, yang akan peneliti jadikan informan adalah Branch Manager, Operation Manager, Customer Service serta nasabah bank Muamalat Cabang Palangka Raya.

Metode pengumpulan data merupakan suatu hal yang penting dalam penelitian, karena dalam metode ini merupakan strategi untuk mendapatkan data yang diperlukan. Tahap-tahap yang dilakukan dalam penelitian berupa penempatan subjek penelitian informasi yang dilakukan. Pengumpulan data yang digunakan dalam penelitian ini adalah observasi, wawancara, dan dokumentasi. 
Berdasarkan semua itu maka peneliti mengolah data kualitatif sehingga dapat diambil suatu kesimpulan atau makna yang valid serta metode yang sebaiknya untuk menganalisis data kualitatif agar dapat memenuhi syarat ilmiah dalam penelitian. Penelitian ini menggunakan tekhnik analisa data kualitatif, data di olah sehingga dapat di ambil kesimpulan atau makna yang valid, serta metode yang sebaiknya untuk menganalisis data kualitatif agar dapat memenuhi syarat ilmiah dalam penelitian. Untuk menganalisis data kualitatif yang diperoleh dari lapangan, peneliti menggunakan proses analisa data dari Miles dan Huberman dalam (Saldana, 2014) Tahapan analisa data kualitatif di atas dapat dilihat pada bagan berikut ini:

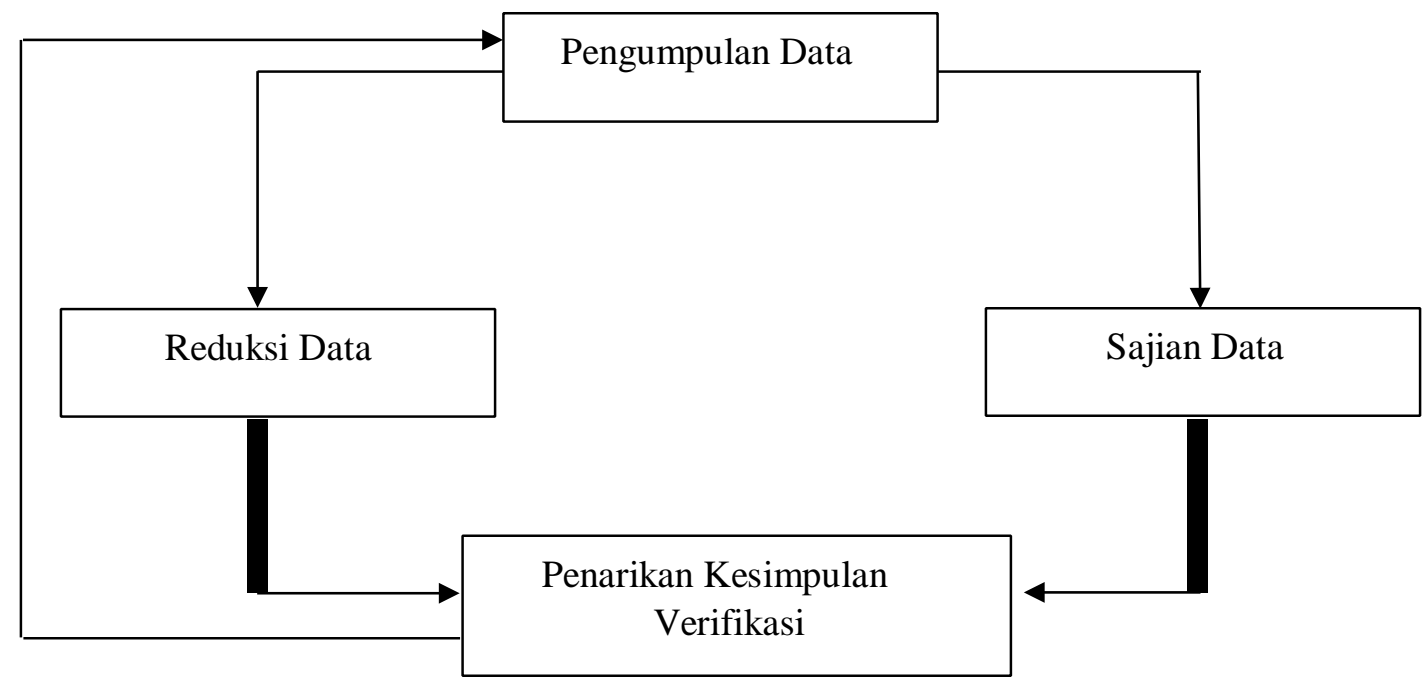

Gambar 1. Model Analisis Data Interaktif

Sumber: Saldana, 2014

\section{HASIL DAN PEMBAHASAN}

Dari hasil wawancara yang disampaikan oleh salah seorang nasabah selama menjadi nasabah Bank Muamalat Indonesia cabang Palangka Raya ini masih merasa cukup puas dengan pelayanan yang diberikan oleh bank maupun bagian customer service. Customer service melayani dengan penuh kesabaran dan ketelatenan, jika ada nasabah yang bertanya didengarkan baik-baik dan dijawab pula dengan baik-baik. Jadi itu sudah mencerminkan 
pelayanan yang baik yang dilakukan oleh Bank Muamalat Indonesia cabang Palangka Raya terhadap para nasabahnya. Selain customer service ada hal lain yang mendukung yaitu adanya kenyamanan dalam bertransaksi yang didukung oleh fasilitas yang nyaman dan lengkap yang dimiliki oleh Bank Muamalat Indonesia cabang Palangka Raya. Sekompetensi-kompetensinya customer service tetapi juga masih ada kekurangan, manusia memang tidak ada yang sempurna, kesempurnaan adalah milik Allah semata. Jadi terkadang customer service juga dalam pelayanannya masih lambat ketika banyak nasabah yang datang, meskipun begitu customer service sudah memberikan pelayanan sebaik mungkin, senyaman mungkin untuk nasabah.

Bank Muamalat Cabang Palangka Raya sudah memberikan pelayanan maksimalnya kepada para nasabah. Customer service juga selalu berusaha memahami dan memberikan solusi tentang semua keluhan yang nasabah sampaikan diwaktu nasabah mempertanyakan apa yang nasabah tidak mengerti serta dengan sikap yang sopan, ramah dan telaten tersebut dapat menarik nasabah agar nasabah tetap nyaman menggunakan jasa Bank Muamalat Indonesia Cabang Palangka Raya ini.

Sementara itu penyampaian informasi juga mengalami kendala, mungkin karena masyarakat ataupun nasabah awam dalam dunia perbankan. Itu menjadi salah satu tugas penting yang harus dilakukan oleh customer service yaitu menjelaskan dengan pelan, sabar, telaten dan teliti kepada para nasabah agar transaksi yang dilakukan antara nasabah dan bank khususnya Bank Muamalat Indonesia Cabang Palangka Raya dapat dilakukan secara tepat dan cepat dan semua kegiatan menjadi mudah dan lancar serta Bank Muamalat Indonesia Cabang Palangka Raya ini dalam menyampaikan informasi sudah sangat mudah dipahami.

\section{Efektivitas customer service dalam meningkatkan loyalitas nasabah penabung di Bank Muamalat Indonesia Cabang Palangka Raya.}

Berdasarkan teori Kasmir, Customer service berperan dalam memberikan pelayanan yang terbaik pada nasabah yang ingin bertransaksi dengan bank. Secara umum, peranan customer service bank adalah sebagai berikut :

a. Mempertahankan nasabah lama agar tetap setia menjadi nasabah bank kita melalui pembinaan hubungan yang lebih akrab dengan nasabah; 
b. Berusaha untuk mendapat nasabah baru, melalui berbagai pendekatan. Misalnya meyakinkan nasabah untuk menjadi nasabah kita dan mampu meyakinkan nasabah tentang kualitas produk kita.

Dari hasil penelitian yang dilakukan pada Bank Muamalat Indonesia Cabang Palangka Raya bahwasanya, peranan customer service terhadap nasabah Bank Muamalat Indonesia Cabang Palangka Raya itu sangatlah penting, menjadikan pelayanan menjadi suatu hal yang harus terus diperbaiki dan dipertahankan mengingat persaingan didunia perbankan untuk mempertahankan nasabah ataupun mencari calon nasabah untuk menjadi nasabah kita itu sulit dan sekaligus customer service merupakan jembatan penghubung atau perantara bagi bank dan nasabah yang ingin mendapatkan pelayanan jasa-jasa ataupun produk-produk bank yang tersedia.

Diantara kemudahan yang diberikan oleh customer service Bank Muamalat Indonesia Cabang Palangka Raya yaitu:

a. Menyediakan sarana dan prasarana yang menunjang transaksi . Bank Muamalat Indonesia menyediakan sarana dan prasarana yang menunjang para nasabah dan pegawainya merasa nyaman melakukan transaksi, memberi kenyamanan dan kemudahan dalam tiap transaksi.

b. Melayani secara cepat dan tepat. Pelayanan yang diberikan oleh Bank Muamalat Indonesia Cabang Palangka Raya yaitu dengan pelayanan yang cepat dengan tersedianya ATM, SMS banking, SalaMuamalat, Muamalat Mobile Banking, Internet Banking dan lain-lain. Pelayanan yang diberikan sangat bersahabat sehingga tepat sasaran.

c. Melayani dengan penuh kesabaran dan menghargai nasabah. Masyarakat atau nasabah Bank Muamalat Indonesia Cabang Palangka Raya umumnya adalah orang awam yang belum mengenal tentang dunia perbankan, oleh karena itu customer service pada Bank Muamalat Indonesia Cabang Palangka Raya melayani dengan penuh kesabaran, ketelatenan, menjelaskan agar para nasabah paham dari awal sampai dengan akhir, penghargaan diri yang diberikan oleh para customer service akan memberikan timbal balik yang 
besar dari nasabah kepada Bank Muamalat Indonesia yang berlegalitas sebagai Bank Syariah.

d. Jika nasabah bertanya dijawab dengan jelas dan dengan senyum, sikap sopan, ramah dan selalu bersikap tenang. Sehubungan dengan nasabah Bank Muamalat Indonesia Cabang Palangka Raya yang tergolong masyarakat awam tentang dunia perbankan, maka secara otomatis banyak nasabah yang akan mengadu dan bertanya kepada customer service dan dari pemaparan yang peneliti lakukan bahwa customer service pada Bank Muamalat Indonesia Cabang Palangka Raya memiliki kepribadian yang baik dimana dalam melayani nasabah selalu bersikap baik apabila bertanya dijawab dengan jelas dan tepat sehingga mudah dipahami dan dimengerti, penuh senyum, sikap sopan santun serta selalu berlaku tenang, tidak gegabah dalam setiap keputusan, apabila tidak mampu menyelesaikan masalah segera meminta bantuan pegawai lain yang mengerti sehingga permasalahan segera bisa diatasi.

e. Memiliki pegawai yang berkompeten. Pegawai atau customer service yang berkompeten merupakan salah satu kunci alternative pemecahan masalah, karena dengan kompetensi yang dimiliki otomatis customer service akan selalu dengan cepat tanggap dan secara tepat dengan kemampuannya melayani nasabah dengan baik, diharapkan dengan kompetensi yang dimiliki customer service bisa bersikap ramah, sopan dan tekun serta teliti, sabar menghadapi sifat dari nasabah yang berbeda-beda.

\section{Loyalitas nasabah penabung di Bank Muamalat Indonesia Cabang Palangka Raya}

Loyalitas pelanggan adalah kunci sukses suatu usaha dalam menjalin hubungan jangka panjang antara perusahaan dengan pelanggannya. Pelanggan yang loyal merupakan aset penting bagi perusahaan, hal ini dapat dilihat dari karakteristik yang dimilikinya.

Berdasarkan hasil wawancara yang peneliti lakukan kepada beberapa nasabah mengenai loyalitas nasabah Bank Muamalat Indonesia Cabang Palangka Raya dapat diketahui bahwa keinginan mereka untuk terus menggunakan jasa dari Bank Muamalat 
Indonesia Cabang Palangka Raya, menunjukan adanya kepuasan atas layanan yang diberikan selama ini. Terciptanya kepuasan nasabah menunjukan adanya sikap loyal dari nasabah terhadap Bank Muamalat Indonesia Cabang Palangka Raya. Pihak nasabah dalam kondisi ini merasakan bahwa bank lainnya belum tentu mampu memberikan pelayanan yang lebih baik dibandingkan dengan bank Bank Muamalat Indonesia Cabang Palangka Raya. Hal ini terlihat dari jawaban para nasabah yang menyatakan bahwa mereka menyimpan sebagian uang tabungannya hampir sebagian besar di Bank Muamalat Indonesia Cabang Palangka Raya, jadi bisa disimpulkan bahwa Bank Muamalat Indonesia Cabang Palangka Raya mampu memikat para nasabahnya untuk menyimpan uangnya di bank tersebut dan dengan pelayanan yang maksimal, fasilitas yang memadai nasabahpun akan tetap nyaman dan loyal pada Bank Muamalat Indonesia Cabang Palangka Raya.

\section{KESIMPULAN DAN SARAN}

\section{Kesimpulan}

Berdasarkan uraian dan paparan hasil penelitian yang peneliti sajikan pada hasil sebelumnya, dengan judul "Peranan Customer Service Dalam Meningkatkan Loyalitas Nasabah Penabung Pada Bank Muamalat Indonesia Cabang Palangka Raya", maka dapat ditarik beberapa kesimpulan yaitu:

1. Efektivitas customer service dalam meningkatkan loyalitas nasabah penabung di Bank Muamalat Indonesia Cabang Palangka Raya. Dari hasil penelitian yang dilakukan di Bank Muamalat Indonesia Cabang Palangka Raya dapat ditarik kesimpulan bahwasanya efektivitas customer service dalam meningkatkan loyalitas nasabah sangatlah penting melalui pelayanan yang diberikan oleh bagian customer service. Pelayanan customer service berupa memberikan kemudahan kepada para nasabah, karena customer service merupakan jembatan penghubung atau perantara bagi bank dan nasabah yang ingin mendapatkan pelayanan jasa-jasa ataupun produkproduk bank yang tersedia. Diantara kemudahan-kemudahan yang diberikan oleh Bank Muamalat Indonesia Cabang Palangka Raya khususnya yang diberikan oleh customer service kepada nasabah yaitu dengan memberikan: pertama Menyediakan sarana dan prasarana yang 
menunjang transaksi, kedua Melayani secara cepat dan tepat kepada nasabah yaitu dengan adanya ATM, SMS banking, SalaMuamalat, Muamalat Mobile Banking, Internet Banking dan lain-lain, ketiga Melayani dengan penuh kesabaran dan menghargai nasabah, keempat Jika nasabah bertanya dijawab dengan jelas dan dengan senyum, sikap sopan, ramah dan selalu bersikap tenang.

2. Loyalitas nasabah penabung di Bank Muamalat Indonesia Cabang Palangka Raya. Berdasarkan hasil penelitian yang dilakukan di Bank Muamalat Indonesia Cabang Palangka Raya kepada beberapa nasabah mengenai loyalitas nasabah dapat diketahui dengan keinginan mereka untuk terus menggunakan jasa dari Bank Muamalat Indonesia Cabang Palangka Raya, itu bisa ditunjukkan dari adanya kepuasan mereka atas layanan yang diberikan selama ini. Terciptanya kepuasan nasabah menunjukan adanya sikap loyal dari nasabah terhadap Bank Muamalat Indonesia Cabang Palangka Raya. Hal ini juga terlihat dari jawaban para nasabah yang menyatakan bahwa mereka menyimpan sebagian uang tabungannya hampir sebagian besar di Bank Muamalat Indonesia Cabang Palangka Raya.

\section{Saran}

1. Bagi Lembaga Perbankan Syariah. Berdasarkan penelitian yang telah peneliti lakukan pada Bank Muamalat Indonesia Cabang Palangka Raya, dengan membuka kantor cabang di Kota Palangka Raya sangatlah menarik perhatian nasabah untuk setia bertransaksi dan menabung di Bank Muamalat Indonesia Cabang Palangka Raya karena bagi mereka Bank Muamalat Indonesia sangat memuaskan dan menyenangkan terutama dalam hal pelayanan yang diberikan oleh customer service. Hubungan baik antara nasabah dan pihak Bank Muamalat Indonesia Cabang Palangka Raya hendaknya dipertahankan dan semoga dalam perjalanannya Bank Muamalat Indonesia Cabang Palangka Raya bisa bekerja sekaligus beribadah mengabdikan diri membantu sesama sesuai dengan legalitasnya bank syariah yang berprinsip tolongmenolong dengan penerapan sistem bagi hasil yang menguntungkan kedua belah pihak. 
2. Bagi peneliti Selanjutnya. Bank Muamalat Indonesia adalah salah satu bank syariah di Indonesia dan merupakan bank syariah pertama yang berdiri di Indonesia. Sampai saat ini sudah memiliki beberapa cabang dan cabang pembantu. Bank Muamalat Indonesia memiliki pengaruh besar terhadap perekonomian, membantu masyarakat dengan memberikan produk-produk yang membanggakan, bagi hasil yang menguntungkan dan kualitas pelayanan yang memuaskan. Karena dengan itu Bank Muamalat Indonesia tetap biasa eksis sampai sekarang dan banyak sekali peluang yang bisa diteliti ataupun dipelajari. Untuk kelemahan atau keterbatasan penelitian ini yaitu hanya pada nasabah penabung saja. Jadi untuk peneliti selanjutnya bisa mengadakan penelitian yang lebih luas lagi seperti nasabah pembiayaan tidak hanya nasabah penabung.

\section{REFERENSI}

Antonio, Muhammad Syafi'i. 2001. Bank Syariah Dari Teori ke Praktik. Jakarta: Gema Insani.

Hanum, F. 2018. Akuntabilitas Keuangan Desa (Studi Kasus Desa Ngentrong Kecamatan Karangan Kabupaten Nganjuk). Mediasosian, Vol. 2(1), hal. 51-56.

Hurriyati, Ratih. 2014. Bauran Pemasaran dan Loyalitas Konsumen. Bandung: ALFABETA.

Kasmir. 2005. Pemasaran Bank. Jakarta: Kencana.

Mujiarto, M., Susanto, D., \& Bramantyo, R. Y. 2019. Strategi Pelayanan Kesehatan Untuk Kepuasan Pasien Di UPT Puskesmas Pandean Kecamatan Dongko Kabupaten Trenggalek. Jurnal Mediasosian: Jurnal Ilmu Sosial Dan Administrasi Negara, 3(1).

Saldana. 2014. Qualitative Data Analysis, A Methods Sourcebook. UI-Press.

Suwarno, S., \& Bramantyo, R. Y. 2019. Pertumbuhan Ekonomi Kreatif Masyarakat Sekitar Hutan Lindung dan Hutan Produksi di Kecamatan Ngancar Kabupaten Kediri. Mediasosian, Vol. 3(2).

Taylor, S. A., Celuch, K., \& Goodwin, S. 2004. The importance of brand equity to customer loyalty. Journal of Product \& Brand Management. 
Tan, Inggrid. Bisnis dan Investasi Sistem Syariah. Yogyakarta: Universitas Atma Jaya Yogyakarta. Undang-Undang No. 10 Tahun 1998

Taylor, S.A., Celuch, K. dan Goodwin, S. 2004, "The importance of brand equity tocustomer loyalty", Journal of Product and Brand Management, Vol. 13 No. 4, pp. 217-227 